\title{
KONSTYTUCYJNY MODEL PREZYDENTURY W REPUBLICE BIAŁORUŚ
}

Wprowadzenie instytucji prezydenta w Republice Białoruś na mocy postanowień konstytucji z 15 marca 1994 r. poprzedziły ostre spory co do zasadności takiej decyzji ${ }^{1}$. W pracach konstytucyjnych, zainicjowanych przez Radę Najwyższą Białoruskiej Socjalistycznej Republiki Radzieckiej w dniu 20 czerwca 1990 r. powołaniem w tym celu Komisji Konstytucyjnej², początkowo przeważał nawet pogląd o braku celowości utworzenia tej instytucji, z czasem jednak zaczął przeważać pogląd przeciwny. Wśród zwolenników tego drugiego poglądu ogromnie kontrowersyjna okazała się być z kolei sprawa umiejscowienia prezydenta w strukturze władzy państwowej: albo jako organu nieprzynależącego do jakiegokolwiek rodzaju władzy, albo jako głowy państwa i szefa (zwierzchnika) władzy wykonawczej. Nie mniej dyskusji wywoływał równolegle omawiany problem statusu prezydenta w systemie rządów: czy ma być wiodącym ogniwem aparatu państwowego, wyposażonym w silną władzę, czy też jego władza powinna być ograniczona, przy jednoczesnym uznaniu dominacji parlamentu w strukturze władzy państwowej.

Niewątpliwym utrudnieniem $\mathrm{w}$ rozstrzyganiu wskazanych kwestii ustrojowych był brak rodzimego wzorca, jakim mogły być doświadczenia w ich praktykowaniu w ramach własnej państwowości. Wprawdzie na historię konstytucyjną Białorusi składały się cztery konstytucje (uchwalone: w dniu 3 lutego 1919 r. przez I Ogólnobiałoruski Zjazd Rad, w dniu 11 kwietnia 1927 r. przez VIII Ogólnobiałoruski Zjazd Rad, w dniu 19 lutego 1937 r. przez XII Nadzwyczajny Zjazd Rad BSRR oraz w dniu 14 kwietnia 1978 r. przez Radę Najwyższą BSRR), ale żadna $\mathrm{z}$ nich nie mogła posłużyć jako wzorzec w pracach konstytucyjnych toczących się na początku lat dziewięćdziesiątych ubiegłego wieku. Wspólną cechę wymienio-

1 O sporach dotyczących instytucji prezydenta w toku prac konstytucyjnych zob. W. Kuczinskij, Problemy zabezpieczenia podziału władz w Republice Białoruś. Historia, stan obecny, perspektywy, (w:) A. Łopatka (red.), Ku konstytucji społeczeństwa obywatelskiego, Warszawa 1995, s.145; T. Szymczak, Republika Białoruś, (w:) W. Brodziński, D. Górecki, K. Skotnicki, T. Szymczak, Wzajemne stosunki między władzą ustawodawczą a wykonawczą (Białoruś, Czechy, Litwa, Rumunia, Słowacja, Węgry), Łódź 1996, s. 22-23.

2 W tym samym dniu Rada Najwyższa podjęła uchwałę o przygotowaniu deklaracji suwerenności państwowej Republiki Białoruskiej. Deklarację tę Rada Najwyższa przyjęła w dniu 27 lipca 1990 r. 
nych dokumentów stanowiło nie tylko to, że były one ustawami zasadniczymi niesuwerennych w rzeczywistości organizmów państwowych. Oprócz tego wszystkie one „posiadały jawnie klasowy charakter, utrwalały jako panującą jedną tylko ideologię, wykluczały wielopartyjność, różnorodność form własności, wszystko było podporządkowane interesom początkowo socjalistycznego, a następnie komunistycznego budownictwa"’3. Do ogólnej specyfiki tych konstytucji należy również zaliczyć, charakterystyczne dla konstytucjonalizmu państw socjalistycznych, oparcie struktury i zasad działania systemu organów państwowych na założeniach jedności władzy państwowej, odrzucających możliwość konkurencji i hamowania poszczególnych segmentów władzy państwowej, jak też ich wzajemną niezależność i separację, a deklarujących skupienie pełni władzy w wybieralnych organach, ze zgromadzeniem ogólnokrajowym jako najwyższym ogniwem na szczycie ich struktury. W skonstruowanym na tych zasadach systemie organów państwowych nie było miejsca dla jednoosobowej głowy państwa.

Wzorców nie dostarczył także konstytucjonalizm państwa federalnego, w skład którego wchodziła Białoruska Socjalistyczna Republika Radziecka, czyli Związku Socjalistycznych Republik Radzieckich. Dogmatem ustrojowym tego państwa było twierdzenie o całkowitym nieprzystawaniu do socjalistycznych pryncypiów ustrojowych instytucji jednoosobowej głowy państwa - prezydenta, a ich spełnianiu przez kolegialny organ pełniący tę funkcję, najlepiej będący „emanacją” parlamentu (w ZSRR było to Prezydium Rady Najwyższej) ${ }^{4}$. Jakiekolwiek próby podważenia tego dogmatu były sprawnie poskramiane ${ }^{5}$. Przełom nastąpił dopiero w wyniku uchwalenia w dniu 15 marca 1990 r. przez III Zjazd Deputowanych Ludowych ustawy o utworzeniu urzędu Prezydenta ZSRR . Nadmieńmy, iż podobnie rzecz się miała w większości satelickich państw socjalistycznych (w państwach europejskich wyjątkami były prezydentury: w Czechosłowacji, Jugosławii i Rumunii, do 1960 r.

G.A. Wasiliewicz, Konstitucjonnoje prawo Riespubliki Biełaruś, Mińsk 2009, s. 42.

W referacie wygłoszonym na Nadzwyczajnym VIII Wszechzwiązkowym Zjeździe Rad 25 listopada 1936 r. J. Stalin stwierdził: „Według systemu naszej Konstytucji w ZSRR nie powinno być jednoosobowego prezydenta, wybieranego przez całą ludność na równi z Radą Najwyższą i mogącego przeciwstawiać swą osobę Radzie Najwyższej. W ZSRR prezydent jest kolegialny - i jest nim Prezydium Rady Najwyższej, włącznie z przewodniczącym Prezydium Rady Najwyższej, wybierane nie przez całą ludność, lecz przez Radę Najwyższą, i podporządkowane Radzie Najwyższej. Doświadczenie historii wskazuje, że taka budowa najwyższych organów jest najbardziej demokratyczna i zabezpiecza kraj przed niepożądaną przypadkowością" J. Stalin, Zagadnienia leninizmu, Warszawa 1949, s. 532.

5 Taki los spotkał przedłożony w czasie opracowywania projektu konstytucji ZSRR w 1936 r. wniosek, aby Przewodniczący Prezydium Rady Najwyższej był wybierany nie przez Radę Najwyższą ZSRR, lecz przez obywateli, jak i wniesioną przez N.S. Chruszczowa w 1964 r. do komisji mającej przygotować projekt nowej konstytucji propozycję ustanowienia urzędu prezydenta. Idea ta pojawiła się następnie w 1985 r. po objęciu funkcji sekretarza generalnego KPZR przez M.S. Gorbaczowa, który jednak uznał ją za niewłaściwą dla systemu radzieckiego. Zob. J. Kowalski, Konstytucja Federacji Rosyjskiej a rosyjska i europejska tradycja konstytucyjna, Warszawa-Poznań 2009, s. 281; M.A. Kozak, Stanowlienije instituta priezidienstwa w Biełarusi i za rubieżom http://elib.bsu.by/bitstream/123456789/33380/1/036.pdf (data dostępu: 12.11.2015 r.).

6 O okolicznościach, w jakich doszło do utworzenia tego urzędu oraz urzędu prezydenta Federacji Rosyjskiej zob.: J.A. Tarasowa, Potieriannaja altiernatiwa: stanowlienije nowoj politiczieskoj sistiemy Rossii w 1990-1993 gg., Sankt Petersburg 2012, s. 59-71. 
- w Niemieckiej Republice Demokratycznej) ${ }^{7}$. Po wkroczeniu tych państw na drogę transformacji ustrojowej instytucja prezydenta stała się w latach dziewięćdziesiątych ubiegłego wieku ogólnie przyjętym elementem ich porządku konstytucyjnego.

Twórcy konstytucji Białorusi uchwalonej przez parlament, Radę Najwyższą, w dniu 15 marca 1994 r. za podstawę doktrynalna systemu organów państwowych przyjęli, tak jak to uczyniono również w innych państwach postkomunistycznych, koncepcję trójpodziału władzy. Od tego czasu, niezmiennie do dziś, art. 6 konstytucji zawiera następującą jego charakterystykę: „Państwo opiera się na zasadzie rozdzielenia władz: ustawodawczej, wykonawczej i sądowniczej. Organy państwowe są samodzielne w zakresie swych kompetencji: współdziałają one ze sobą, powstrzymują się i równoważą nawzajem". Ustawa zasadnicza umiejscowiła prezydenta w strukturze władzy wykonawczej, jako głównego jej elementu, głosząc w art. 95, iż „Prezydent Republiki Białoruś jest głową państwa i władzy wykonawczej”. Wyrazem jego usytuowania na czele władzy wykonawczej było włączenie przepisów o rządzie (Gabinecie Ministrów) do rozdziału zatytułowanego „Prezydent Republiki Białoruś” i uczynienie z rządu organu podległego prezydentowi: „,służebnego względem prezydenta, będącego narzędziem realizacji jego woli"». Stworzony przez konstytucję system rządów, zakładający centralną pozycję w systemie władzy państwowej jednoizbowego parlamentu (Rady Najwyższej Republiki Białoruś), z jednoczesnym przyznaniem prezydentowi władzy w zakresie wykraczającym poza zwykłe standardy systemu parlamentarnego, można było zidentyfikować jako odmianę systemu mieszanego, parlamentarno-prezydenckiego.

W pierwszych wyborach prezydenckich wygrał nie ten z kandydatów, z myślą o którym w konstytucji nadano prezydenturze określony kształt, tj. Wiaczesław Kiebicz, lecz nieoczekiwanie Aleksander Łukaszenko, który wszelkimi sposobami zaczął dążyć do wzmocnienia władzy prezydenckiej. Nakierowana na ten cel tendencyjna interpretacja przepisów konstytucyjnych nie spełniała aspiracji Aleksandera Łukaszenki, toteż - w warunkach ostrego kryzysu politycznego, mimo sprzeciwu m.in. parlamentu i Sądu Konstytucyjnego - przeforsował w głosowaniu referendalnym, zakończonym w dniu 24 listopada 1996 r., własny projekt zmian w konstytucji, umożliwiający prezydentowi sterowanie wszystkimi segmentami władzy ${ }^{9}$. Jak pisze T. Sedelius, przeprowadzone wówczas ,zmiany konstytucyjne skonsolidowały prezydencką dyktaturę podporządkowując wszystkie instytucje prezydenckiemu nadzorowi”, czyniąc z konstytucji „pierwszą ofiarę pierwszego prezydenta”10. Prze-

$7 \quad$ O instytucji prezydenta w warunkach ustrojowych tych państw zob. zwłaszcza T. Szymczak, Ewolucja instytucji prezydenta w socjalistycznym prawie państwowym, Łódź 1976.

8 J. Zaleśny, System konstytucyjny Białorusi, Warszawa 2011, s. 11.

9 O tym referendum zob. szerzej O. Łatyszonek, E. Mironowicz, Historia Białorusi od połowy XVIII do końca XX wieku, Białystok 2002, s. 302-304; P. Usov, Powstanie, konsolidacja i funkcjonowanie reżimu neoautorytarnego na Białorusi w latach 1994-2010, Warszawa 2014, s. 134 i n.; A. Wilson, Belarus. The Last European Dictatorship, New Haven-London 2011, s. 181 i n.

10 T. Sedelius, The Tug-of-War between Presidents and Prime Ministers Semi-Presidentialism in Central and Eastern Europe, Örebro 2006, s. 103. 
pisy konstytucji stworzyły warunki do przejęcia przez prezydenta m.in. roli najważniejszego prawodawcy (m.in. wskutek przekazaniu mu uprawnień ustawodawczych w postaci wydawania dekretów) oraz skupienie władzy w rządzeniu państwem, ustalaniu i prowadzeniu jego polityki. W poważnym stopniu jest przez niego kontrolowana również władza sądownicza. Prezydentowi są też podporządkowane władze lokalne. Dysponuje przy tym ogromnym funduszem na realizację swoich działań, co umożliwia art. 136 konstytucji i odpowiednie ustawy przyznające mu uprawnienie do posiadania środków (funduszy) pozabudżetowych ${ }^{11}$.

Znamienne jest przy tym to, że od wprowadzenia zmian w konstytucji w wyniku referendum z 1996 r. prezydent już nie jest identyfikowany z którąkolwiek z władz, $\mathrm{w}$ tym też władzą wykonawczą. Jest to powszechnie odbierane w białoruskiej nauce prawa konstytucyjnego jako przyznanie prezydentowi osobnego, specjalnego miejsca w systemie organów państwowych ${ }^{12}$, uznanie, iż jest odrębną, samodzielną wła$\mathrm{dzą}^{13}$. Mimo to, dodaje się niekiedy przy tym, że można jednak mówić o określonym dualizmie władzy wykonawczej ${ }^{14}$. Konstatacja ta zyskuje na znaczeniu, jeżeli zważymy, że zgodnie z art. 105 konstytucji władzę wykonawczą w Republice Białoruś sprawuje jedynie rząd - Rada Ministrów. W kontekście dominującej pozycji prezydenta nie dziwi natomiast wysunięcie przepisów go dotyczących na czoło IV rozdziału konstytucji, zatytułowanego „Prezydent, Parlament, Rząd, sąd”.

Skupienie w prezydencie władzy niezwykle silnej, zwierzchniej wobec innych organów państwa, dodatkowo jeszcze wzmacnianej dyktatorskimi metodami sprawowania tego urzędu przez A. Łukaszenkę, oznaczać musiało zerwanie z głoszoną nadal $\mathrm{w}$ art. 6 konstytucji ideą podziału władzy, zanegowanie głoszonej w nim zasady samodzielności, współdziałania, powstrzymywania się i wzajemnego równoważenia organów państwowych. Za celne musimy uznać następujące spostrzeżenie W. Rowdo: „i litera, i duch ustawy zasadniczej z 1996 r., a także realna polityczno -prawna praktyka w naszym kraju w znacznie wyższym stopniu odpowiada nie danej normie konstytucyjnej [tj. art. 6 deklarującemu podział władzy - G.K.], ale dobrze wszystkim znanej wypowiedzi A. Łukaszenki, że »władza prezydencka w Białorusi - to pień «, inne struktury władzy - to "gałęzie, z niego wyrastające»"15. Nieprzekonujące są natomiast twierdzenia „oficjalnych” przedstawicieli białoruskiej nauki prawa konstytucyjnego, jakoby dzięki nowej redakcji konstytucji z 1996 r. system instrumentów powstrzymywania się i równoważenia władz został „uzupełniony i udoskonalony”, a „dla białoruskiego konstytucjonalizmu są charakterystyczne ogólnie uznawane światowe zasady i tendencje", czego wyrazem rzekomo jest to, że

\footnotetext{
11 Zob. M. Maszkiewicz, Republika Białoruś, (w:) W. Baluk i A. Czajowski, (red.) Ustroje polityczne krajów Wspólnoty Niepodległych Państw, Wrocław 2007, s. 81.

Zob. np. G.A. Wasiliewicz, Konstitucjonnoje..., op. cit., s. 223.

Zob. A.W. Maryskin, Osnowy konstitucjonnogo prawa, Mińsk 2005, s. 73.

Zob. W.A. Kodawbowicz, W.A. Krugłow, Konstitucjonnoje prawo Riespubliki Biełaruś, Mińsk 2012, s. 289.

W. Rowdo, Srawnitielnaja politołogija, cz. 3, Politiczieskaja sistiema Riespubliki Biełaruś, Wilno 2009, s. 137.
} 
„W białoruskiej konstytucji realnie i szczegółowo są utrwalone mechanizmy realizacji zasady podziału władz"16.

Białoruska głowa państwa, stosownie do swej pozycji ustrojowej, jest wybierana w wyborach powszechnych i bezpośrednich, co sprawia, że posiada legitymację nominalnego podmiotu władzy suwerennej - narodu. Od kandydatów na ten urząd wymaga się, by byli obywatelami Republiki Białoruś ,z urodzenia”, mieli ukończonych 35 lat, posiadali pełnię praw wyborczych i stale zamieszkiwali Republikę Białoruś przez co najmniej 10 lat bezpośrednio przed wyborami. Prawo zgłaszania kandydatów zostało przyznane obywatelom, przy czym konieczne jest zebranie co najmniej 100 tys. podpisów popierających. Zgodnie z konstytucją wybory uważa się za ważne, jeżeli wzięła w nich udział ponad połowa wyborców ujętych spisami wyborców. Za wybranego natomiast uważa się kandydata, na którego oddała głosy więcej niż połowa obywateli uczestniczących $\mathrm{w}$ głosowaniu. Jeżeli żaden $\mathrm{z}$ kandydatów nie uzyskał wymaganej liczby głosów, wówczas w terminie 2 tygodni jest przeprowadzana druga tura głosowania; rywalizują w niej tylko dwaj kandydaci, którzy otrzymali w pierwszej turze największą liczbę głosów. Za wybranego uznaje się tego z nich, na którego oddano ponad połowę ważnych głosów.

Nadzwyczaj ważna rola w procesie wyborczym przypada Centralnej Komisji ds. Wyborów i Przeprowadzania Referendów Republikańskich, która m.in. może podejmować uchwały, uznawane przez kodeks wyborczy z 11 lutego 2000 r. za podstawowe źródła prawa wyborczego po konstytucji, kodeksie wyborczym i innych aktach ustawodawczych (art. 2), rejestruje grupy inicjatywne obywateli tworzone w celu zgłoszenia kandydata na urząd prezydenta, rejestruje tych kandydatów (może odmówić rejestracji lub unieważnić zarejestrowaną już kandydaturę w dowolnym momencie postępowania przedwyborczego, w razie uznania niezgodności jej zgłoszenia $\mathrm{z}$ wymogami kodeksu ${ }^{17}$ ), podejmuje decyzje w sprawie uznania wyborów za nieważne (może być ona zaskarżona przez każdego z kandydatów w terminie 10 dni) ${ }^{18}$. Podkreślenie znaczenia Centralnej Komisji jest o tyle istotne, gdyż jest ona organem - o czym będzie jeszcze mowa - po połowie składu powoływanym przez prezydenta oraz przez izbę drugą parlamentu, Radę Republiki, personalnie również powiązaną z prezydentem.

Kadencja Prezydenta Republiki Białoruś jest 5-letnia. Początkowo konstytucja białoruska ustanawiała możliwość tylko jednego ponownego wyboru na urząd prezydenta, co jest powszechną regułą w demokratycznych ustrojach państwowych. W referendum przeprowadzonym w dniu 17 października 2004 r., którego dopuszczalność i przebieg zostały zakwestionowane m.in. przez liczne organiza-

\footnotetext{
16 M. Czudakow, Bałans włastiej i drugije principy organizacji i diejatielnosti gosudarstwa: princip sdierżek i protiwowiesow w konstitucii Riespubliki Biełaruś, „Probliemy Uprawlienija” 2008, nr 1, s. 105. Zob. J. Zaleśny, System..., op. cit., s. 31. (red.), Prawo wyborcze na urząd prezydenta w państwach europejskich, Warszawa 2007, s. 39.
} 
cje i instytucje międzynarodowe, w drodze wyjątku została wyrażona zgoda społeczna na kandydowanie prezydenta A. Łukaszenki w trzecich jego wyborach prezydenckich ${ }^{19}$; w kolejnych wyborach zgoda taka już nie była potrzebna, ponieważ w następstwie wspomnianego referendum $\mathrm{z}$ konstytucji zostało również usunięte ograniczenie liczby kadencji.

Konstytucja ustanawia trzy instrumenty w założeniu mające tworzyć przesłanki niezależności prezydenta $\mathrm{w}$ wykonywaniu nałożonych nań zadań. Pierwszym $\mathrm{z}$ nich jest zasada niepołączalności funkcji prezydenta $z$ piastowaniem innych urzędów, drugim - zakaz otrzymywania (poza wynagrodzeniem za jej sprawowanie) innych środków pieniężnych, z wyjątkiem honorariów za prace naukowe, utwory literackie i dzieła sztuki, trzecim - obowiązek zawieszenia na czas sprawowania urzędu członkostwa w partii politycznej i innych organizacjach społecznych mających cele polityczne.

Konstytucja nie przewiduje jakiejkolwiek formy odpowiedzialności politycznej prezydenta. Jedyną wskazaną $\mathrm{w}$ ustawie zasadniczej postacią odpowiedzialności głowy państwa jest odpowiedzialność konstytucyjna. Procedura egzekwowania tej odpowiedzialności ma pewne znamiona impeachmentu i obejmuje określone czyny będące przestępstwami. Przyczynami jej wszczęcia mogą być: dopuszczenie się zdrady stanu lub popełnienie innego ciężkiego przestępstwa. Wniosek w tej sprawie może przedstawić 1/3 składu Izby Reprezentantów, natomiast przeprowadzenie śledztwa oraz postawienie w stan oskarżenia należy do Rady Republiki. O usunięciu z urzędu rozstrzygają obie izby parlamentu kwalifikowaną większością 2/3 ogólnego składu każdej z nich.

Artykuł 79 konstytucji Republiki Białoruś wskazuje na trzy główne role prezydenta: jako głowy państwa, gwaranta konstytucji oraz gwaranta praw i wolności człowieka i obywatela. W tym samym artykule są wymienione inne jeszcze funkcje i zadania prezydenta: uosabianie jedności narodu, gwarantowanie realizacji głównych kierunków polityki wewnętrznej i zagranicznej, reprezentowanie Republiki Białoruś w relacjach z innymi państwami i organizacjami międzynarodowymi, podejmowanie działań mających na celu ochronę suwerenności Republiki Białoruś, jej bezpieczeństwa narodowego i terytorialnej całości, zapewnienie politycznej i ekonomicznej stabilności, jak też współzależności i współdziałania organów władzy państwowej. Z ostatnim ze wskazanych zadań łączy się, również wymieniona w art. 79 konstytucji, funkcja pośrednictwa między organami władzy państwowej, czyli arbitrażu politycznego między władzami. Szczególnymi cechami tego typu arbitrażu w wersji białoruskiej są: jego przede wszystkim polityczny charakter oraz to, że prezydent ,z jednej strony, występuje w roli arbitra, a z drugiej - sam może aktywnie kierować rządem, podległymi jemu organami” ${ }^{20}$. Mając na uwadze ogół przepisów

19 O tym referendum zob. szerzej A. Wilson, Belarus..., op. cit., s. 206 i n.

20 G.A. Wasiliewicz, Konstitucjonnoje..., op. cit., s. 223. 
konstytucji dotyczących kompetencji prezydenckich, funkcję tę można interpretować jako wyraz dążenia do zapewnienia jednolitości działania systemu organów państwowych, w imię ich „współzależności i współdziałania”, zgodnego z wolą prezydenta.

O nadzwyczaj silnej pozycji Prezydenta Republiki Białoruś świadczą nie tylko jedne z najbardziej rozbudowanych na świecie przyznane mu zadania ${ }^{21}$, ale również fakt realizowania kompetencji samodzielnie, tylko z niewielkimi wyjątkami, bez potrzeby kontrasygnowania czy uczestnictwa jakiegokolwiek innego organu (np. wystąpienie z wnioskiem lub uzgodnienie) ${ }^{22}$. Kompetencje prezydenta, odnoszące się do wszystkich segmentów władzy państwowej, są rozległe, umożliwiające władcze oddziaływanie na cały bez mała aparat państwa, zarówno na szczeblu centralnym, jak i lokalnym. Specyfiką rozwiązań białoruskich jest również przyznanie głowie państwa możliwości prawnych wkraczania na obszary gdzie indziej nieobejmowane zakresem działania prezydenta, a przynajmniej wszędzie tam, gdzie idea podziału władzy jest wartością przestrzeganą, a proces sprawowania władzy ma wymiar demokratyczny. Śmiało można stwierdzić, że Prezydent Białorusi jest „siłą sprawczą” funkcjonowania państwa, jego rzeczywistym centrum dyspozycyjnym.

Szczególnego wyeksponowania wymaga niezwykle szerokie zakreślenie przez ustrojodawcę białoruskiego funkcji kreacyjnej prezydenta, przejawiającej się w bezpośrednim powoływaniu i odwoływaniu bardzo wielu organów państwowych, przynależnych - co trzeba podkreślić $\mathrm{z}$ całą mocą - do wszystkich segmentów władzy państwowej.

Funkcja ta ogarnia nawet parlament - dwuizbowe Zgromadzenie Narodowe. W przypadku izby pierwszej, Izby Reprezentantów, wpływ prezydenta na kształtowanie jej składu ma charakter wyłącznie pozaprawny, ale jest bardzo skuteczny. Proces wyborczy do Izby Reprezentantów odbywa się pod ścisłą kontrolą prezydenckiego ośrodka władzy, nie spełniając podstawowych standardów wyborów wolnych i uczciwych, czego widocznym rezultatem jest całkowity brak w Izbie Reprezentantów przedstawicieli opozycji ${ }^{23}$. Co się zaś tyczy izby drugiej, Rady Republiki, przez konstytucję określonej jako „izba przedstawicielstwa terytorialnego”, to ośmiu jej członków jest mianowanych przez prezydenta. Pozostali członkowie, w liczbie pięćdziesięciu sześciu, są wybierani w głosowaniu tajnym na posiedzeniach deputowanych lokalnych rad deputowanych szczebla obwodowego i miasta Mińska, w praktyce jednak pod prezydenckim nadzorem politycznym ${ }^{24}$.

Dla określenia relacji między prezydentem a władzą ustawodawczą kluczowe znaczenie ma następująca konstatacja: wprawdzie konstytucja sprawowanie tej wła-

21 Por. J. Zaleśny, System..., op. cit., s. 34.

22 Zob. G. A. Wasiliewicz, Konstitucjonnoje..., op. cit., s. 224.

23 Izba Reprezentantów, składająca się ze 110 deputowanych, jest wybierana w wyborach powszechnych, wolnych, równych, bezpośrednich i w głosowaniu tajnym. Wybory te są przeprowadzane w okręgach jednomandatowych. 
dzy traktuje jako atrybut parlamentu, to jednak - jak trafnie wskazuje M. Czerwiński - rzeczywistym ,głównym prawodawcą" jest prezydent ${ }^{25}$. I wynika to nie tylko z faktu rzeczywistego podporządkowania prezydentowi parlamentu, którego skład - całkowicie pozbawiony przedstawicieli opozycji - jest w praktyce politycznej formowany pod kontrolą administracji prezydenckiej, ale też z przyznania prezydentowi instrumentów konstytucyjnych umożliwiających mu uczestnictwo w procesie tworzenia prawa, w tym zwłaszcza uprawnienie do wydawaniu aktów o mocy równej ustawom zwykłym, a nawet wobec nich nadrzędnych.

Zgodnie z art. 101 konstytucji izby parlamentu, tj. Izba Reprezentantów i Rada Republiki, mogą większością głosów pełnych swoich składów, na wniosek prezydenta, udzielić mu pełnomocnictwa do wydawania dekretów z mocą ustawy; w akcie tym musi być określony przedmiot regulacji oraz termin trwania upoważnienia. Konstytucja zastrzega też, iż niedopuszczalne jest przekazywanie pełnomocnictw do wydawania dekretów prowadzących do zmiany lub uzupełnienia w konstytucji, a także jej interpretacji, zmiany lub uzupełnienia ustaw programowych, zatwierdzenia budżetu i sprawozdania z jego wykonania, zmiany trybu wyborów prezydenta i parlamentu, jak też ograniczenia konstytucyjnych praw i wolności obywateli. Konstytucja $\mathrm{w}$ art. 101 oprócz tego ustanawia instytucję dekretów tymczasowych, które mogą być wydawane przez prezydenta, w sytuacji szczególnej konieczności, z własnej jego inicjatywy lub na wniosek rządu.

Dla ustalenia miejsca obu tych kategorii dekretów w hierarchii źródeł prawa, wyższego nawet od ustaw, kluczowe znaczenie mają: 1) art. 137 konstytucji, głoszący, iż w razie rozbieżności dekretu z ustawą, aktem nadrzędnym jest ustawa tylko wówczas, gdy pełnomocnictwa do wydania dekretu lub prezydenckiego były przewidziane ustawą; 2) art. 28 ustawy z dnia 21 lutego 1995 r. o prezydencie Republiki Białoruś, odnoszący do dekretów zasadę ich nadrzędności - o ile konstytucja nie stanowi inaczej - wobec aktów wszystkich innych organów państwowych i osób urzędowych.

Pomimo założenia ustrojodawcy białoruskiego, iż wydawanie dekretów tymczasowych będzie praktykowane wyjątkowo ${ }^{26}$, to jednak stały się one rzeczywistą, często stosowaną postacią realizacji funkcji prawodawczej prezydenta ${ }^{27}$; dekrety wydawane na podstawie delegacji ustawowej są natomiast instytucja martwą̨ ${ }^{28}$. Praktyce tej nie przeciwstawia się w ogóle parlament, któremu konstytucja przyznała prawo do uchylania dekretów tymczasowych, większością co najmniej 2/3 głosów ustawowej liczby członków każdej z izb. Istotne jest, że ustawa zasadnicza nie usta-

M. Czerwiński, Prezydent jako głowa władzy wykonawczej - model białoruski, (w:) M. Drzonek, A. Wołek (red.), Władza wykonawcza w Polsce i Europie, Kraków-Nowy Sącz 2009, s. 196.

26 Zob. szerzej D.A. Łagun, Juridiczieskij status wriemiennych diekrietow, „Wiesnik BDU” 2010, seria 3, nr 3, s. 87.

27 Do 2006 r. prezydent wydał 258 dekretów tymczasowych. Zob. W. Rowdo, Srawnitielnaja..., op. cit., s. 137.

28 Por. M.S. Pietrowa, Normatiwnyje prawowyje akty Prezidienta Riespubliki Biełaruś i ich miesto w sistiemie zakonodatielstwa, (w:) Uprawlienije w socjalnych i ekonomiczieskich sistiemach. XVII mieżdunarodnaja nauczno -prakticzieskaja konfieriencija (Minsk, 2-6 ijunia 2008 g.), Mińsk 2008, s. 331. 
nawia wobec dekretów tymczasowych ograniczeń co do ich przedmiotu, tak jak to czyni w odniesieniu do dekretów wydawanych w oparciu o delegację ustawową. Korzystając $\mathrm{z}$ tego A. Łukaszenko wielokrotnie ingerował w sprawy niemogące być w ogóle regulowane tymi dekretami, w drodze wydawania dekretów tymczasowych, dotyczących zwłaszcza praw i wolności człowieka i obywatela ${ }^{29}$.

Prezydentowi Republiki Białoruś zostały ponadto powierzone bardzo poważne uprawnienia i przywileje pozwalające mu skutecznie angażować się w proces ustawodawczy, a nawet go kontrolować ${ }^{30}$. W pierwszej kolejności należy wspomnieć o prawie inicjatywy ustawodawczej, z którego - notabene - A. Łukaszenko korzysta często. Prawo to ponadto przysługuje: deputowanym Izby Reprezentantów, Radzie Republiki, rządowi oraz co najmniej 50 tys. obywateli posiadających prawa wyborcze. Swobodę korzystania z tego prawa ogranicza wymóg wnoszenia wyłącznie za zgodą prezydenta, lub na jego polecenie - rządu, projektów ustaw, których skutkiem może być zmniejszenie środków państwowych, powstanie lub zwiększenie wydatków. Konstytucja oprócz tego przewiduje możliwość uznania przez prezydenta, lub na jego polecenie przez rząd, wnoszonego projektu ustawy za pilny, co tworzy obowiązek Izby Reprezentantów i Rady Federacji rozpatrzenia takiego projektu w przeciągu 10 dni od jego przedłożenia. Uprzywilejowanie prezydenta w procesie stanowienia ustaw jeszcze bardziej wzmacnia powierzone mu prawo do żądania, by Izba Reprezentantów i Rada Republiki na swoich posiedzeniach głosowały wyłącznie nad całym projektem ustawy w wersji przedstawionej przez niego lub rząd, albo jego częścią, zachowując tylko poprawki, które były przedstawione lub przyjęte przez prezydenta ewentualnie rząd. Dodajmy, że z żądaniem takim może wystąpić również rząd, lecz za zgodą prezydenta.

Konstytucja przypisuje prezydentowi jeszcze jedną bardzo ważną rolę w postępowaniu ustawodawczym w sytuacji, gdy Rada Republiki odrzuci projekt ustawy uchwalony wcześniej przez Izbę Reprezentantów i stworzona przez obie izby parlamentu komisja porozumiewawcza nie wypracuje uzgodnionego tekstu ustawy. W sytuacji takiej prezydent (lub na jego polecenie - rząd) może zażądać, by ostateczną decyzję co do danej ustawy podjęła Izba Reprezentantów. Warunkiem przyjęcia w ten sposób ustawy jest jej poparcie przez większość co najmniej 2/3 ogółu deputowanych tej izby parlamentu.

Prezydent uchwaloną już ustawę, która wzbudza jego sprzeciw, ma prawo zawetować (może to być weto całkowite i weto selektywne) i odesłać ją z przedstawionymi zastrzeżeniami do izby pierwszej parlamentu, tj. Izby Reprezentantów. Izba ta ma obowiązek rozpatrzenia tej ustawy w ciągu 30 dni. Jeśli w tym terminie uchwali ona ponownie ustawę większością co najmniej $2 / 3$ swego składu, to następnie jest ona przekazywana, wraz z zastrzeżeniami prezydenta, w terminie 15 dni, do izby

29 Zob. W. Rowdo, Srawnitielnaja..., op. cit., s. 138.

30 O trybie ustawodawczym zob. szerzej M. Czerwiński, Zgromadzenie Narodowe Białorusi, Warszawa 2008, s. $21 \mathrm{in}$. 
drugiej parlamentu, Rady Republiki, która musi ją rozpatrzeć powtórnie nie później niż w przeciągu 20 dni. Ustawę uważa się za uchwaloną, jeżeli głosy na nią odda co najmniej 2/3 ogólnej liczby członków tej izby. W przypadku przezwyciężenia sprzeciwu prezydenta przez obie izby ustawa musi być podpisana przez niego w ciągu 5 dni; jeśli jednak nie zostanie podpisana $\mathrm{w}$ tym terminie, to $\mathrm{z}$ jego upływem wchodzi w życie z mocy prawa.

Ważną instytucją, zapewniającą prezydentowi sterowanie procesem ustawodawczym, jest Narodowe Centrum Ustawodawstwa i Badań Prawnych Republiki Białoruś (Nacjonalnyj Cientr Zakonodatielstwa i Prawowych Issliedowanij Riespubliki Biełaruś), które w 2005 r. powstało na bazie powołanego w 1997 r. Centrum Projektowania Ustaw przy Prezydencie Republiki Białoruś (Cientr Zakonodatielnoj Diejatielnosti pri Priezidientie Riespubliki Biełaruś)). Narodowe Centrum jest instytucją podległą prezydentowi, który m.in. nadaje mu regulamin, zatwierdza roczne plany działalności, ustala strukturę organizacyjną oraz rozstrzyga o najważniejszych sprawach kadrowych. Stanowi ono nie tylko płaszczyznę oddziaływania na treść ustaw, ale też jest bardzo użytecznym filtrem nieprzepuszczającym projekty ustaw nieaprobowane przez prezydenta.

W związku z aktywnością prezydenta dotyczącą stanowienia praw koniecznych jest jeszcze odnotowanie uprawnienie prezydenta do inicjowania postępowania w sprawie zmiany lub uzupełnienia konstytucji, stwarzające mu możliwość oddziaływania na kształt ustroju państwa ${ }^{31}$. Symptomatyczne jest przy tym to, że prawo do wniesienia odpowiedniego projektu ustawy zostało przyznane tylko głowie państwa i obywatelom (w liczbie nie mniejszej niż 150 tys.), z pominięciem członków parlamentu oraz rządu. Do uchwalenia zmiany wymagane jest zgodne głosowanie Izby Reprezentantów i Rady Republiki, kwalifikowaną większością co najmniej 2/3 głosów ustawowych składów każdej z izb. Zmiany i uzupełnienia konstytucji mogą również być dokonywane $\mathrm{w}$ drodze referendum, nadmieńmy: zarządzanego przez prezydenta. W przypadku zmian czterech rozdziałów konstytucji jest ono obligatoryjne ${ }^{32}$. Nie wyłącza to jednak całkowicie możliwości parlamentu ingerencji w ich treść. W doktrynie białoruskiej głoszony jest bowiem pogląd, że parlament może wprowadzać uzupełnienia do wspomnianych rozdziałów, nienaruszające zasadniczej istoty zawartych w nich postanowien ${ }^{33}$.

Konstytucja Republiki Białoruś nie ogranicza się do przyznania prezydentowi, opisanych wyżej, kompetencji wiążących się z funkcją ustawodawczą i ustrojodawczą parlamentu, wyposażając go również w instrumenty ogólnego oddziaływania na parlament wykraczające poza sferę tej funkcji.

\footnotetext{
31 O procedurze zmian konstytucji w Białorusi zob. szerzej w: J. Rychlik, Zasady zmiany Konstytucji Republiki Białorusi, (w:) R. Grabowski, S. Grabowska (red.), Zasady zmiany konstytucji w państwach europejskich, Warszawa 2008, s. 49 i n.

Są następujące rozdziały: „Podstawy ustroju konstytucyjnego” (I), „Jednostka. Społeczeństwo, Państwo” (II), „Prezydent, Parlament, Rząd i sąd” (IV) i „System finansowo-kredytowy Republiki Białoruś” (VIII). 
Prawną formą takiego oddziaływania jest uprawnienie do zwoływania sesji nadzwyczajnych izb parlamentu, które prezydent może zwoływać z własnej inicjatywy lub na wniosek co najmniej 2/3 ustawowej liczby członków każdej z izb. Konstytucja tworzy ogólne podstawy wywierania przez prezydenta wpływu na bieżące prace izb parlamentu, umożliwiając mu bezpośrednie kontaktowanie się z nimi. W szczególności stanowi, iż zwraca się on do parlamentu z corocznymi orędziami, które są wysłuchiwane na posiedzeniach Izby Reprezentantów i Rady Republiki, bez przeprowadzania debaty. Ustawa zasadnicza formułuje też ogólnikowo prawo prezydenta do uczestniczenia w pracy parlamentu i jego organów, występowania przed nimi w każdym czasie z przemówieniami i informacjami. Konkretyzacja postępowania realizującego to prawo jest dokonana $w$ regulaminach izb parlamentu.

Za zwieńczenie konstytucyjnych uprawnień Prezydenta Republiki Białoruś wobec władzy ustawodawczej można uznać nadzwyczaj szerokie, zakreślone normami konstytucji, spoczywające $w$ jego rękach, możliwości przedterminowego rozwiązania parlamentu. Przyczynami rozwiązania Izby Reprezentantów, a tym samym całego parlamentu, mogą być: 1) jej odmowa wyrażenia rządowi wotum zaufania; 2) wyrażenie przez nią wotum nieufności rządowi (szczególnym jego przypadkiem jest powtórne odrzucenie przez Izbę Reprezentantów programu działalności rządu ${ }^{34}$ ), 3) dwukrotne niewyrażenie przez nią zgody na mianowanie premiera proponowanego przez prezydenta. $Z$ przytoczonych przyczyn przedterminowego rozwiązania Izby Reprezentantów wywieść należy generalny wniosek, iż ustrojodawca białoruski ponad zaufanie parlamentarne rządu przedłożył jego zaufanie u prezydenta, czego wyrazem jest uzależnienie od jego woli ponoszenia przez rząd odpowiedzialności parlamentarnej.

Konstytucja przewiduje jeszcze jedną przyczynę rozwiązania Izby Reprezentantów, jak i Rady Republiki, na mocy aktu prezydenckiego; przyznać trzeba - oryginalną, ale wkomponowującą się w białoruski reżim autorytarny. Jest nią orzeczone przez Sąd Konstytucyjny „systematyczne lub poważne naruszenie przez izby parlamentu konstytucji” (art. 94). Zaznaczyć należy, że rozpatrzenie przez Sąd Konstytucyjny sprawy ewentualnego podejmowania przez izby takich działań może nastąpić wyłącznie z inicjatywy prezydenta, co oznacza, że od jego uznania zależy interpretacja niejasnych określeń, jakimi są: „,systematyczne” i „poważne” naruszenie konstytucji ${ }^{35}$.

O ile w świetle powyższych ustaleń można śmiało mówić o braku separacji prezydenta w stosunku do parlamentu, to w relacji odwrotnej odstępstwa od niej są wyjątkowe. Odstępstwem takim jest przede wszystkim ponoszenie przez prezydenta - o czym już była mowa - odpowiedzialności konstytucyjnej poprzez zastosowanie procedury nawiązującej do impeachmentu. Inną kompetencją wspólną przyznaną 
Izbie Reprezentantów i Radzie Republiki, z której skorzystanie jest równoznaczne z przedterminowym wygaśnięciem pełnomocnictw prezydenta, jest - stwierdzenie większością $2 / 3$ głosów każdej z izb - niezdolności do sprawowania urzędu ze względu na stan zdrowia. Wniosek w sprawie podjęcia takiej decyzji przedkłada specjalnie w tym celu powołana przez obie izby komisja. Izba Reprezentantów oprócz tego przyjmuje dymisję prezydenta.

Pozostałymi kompetencjami parlamentu odnoszącymi się do prezydenta są: 1) zarządzanie przez Izbę Reprezentantów wyborów prezydenta; 2) wyrażanie zgody przez deputowanych tej Izby na powołanie przez prezydenta premiera, której uregulowanie prawne w rzeczywistości - jak już wspomniano wyżej - wcale nie świadczy o słabej pozycji głowy państwa, lecz przeciwnie - o jego dominacji w procesie kreacji rządu.

Charakter relacji między prezydentem a rządem (Radą Ministrów), przypomnijmy: w świetle konstytucji białoruskiej jedynym organem władzy wykonawczej, wyznacza ogólna zasada stwierdzona w art. 106 Konstytucji, iż „rząd w swojej działalności jest podporządkowany Prezydentowi Republiki Białoruś”. Wyrazem tej zasady są przepisy ustawy zasadniczej oraz ustawy z 23 lipca 2008 r. o Radzie Ministrów Republiki Białoruś, czyniące z prezydenta rzeczywistą głowę władzy wykonawczej, a z Rady Ministrów „organ gospodarczo-administracyjny przy głowie państwa" ${ }^{36}$, „»rząd techniczny«, którego funkcje sprowadzają się tylko do wykonywania i rozpatrywania decyzji prezydenta" ${ }^{37}$, „wiernego pomocnika zasadniczej siły sprawczej - prezydenta, który zastępuje przeszłą do historii niechlubną partię komunistyczną"38.

Rząd białoruski jest jedynym organem, który w konstytucji został określony nie tylko jako sprawujący władzę wykonawczą, ale też jako „,naczelny organ administracji państwowej" (art. 106). W skład rządu - w myśl ustawy zasadniczej - wchodzą obligatoryjnie: premier, zastępcy premiera i ministrowie. Konstytucja stwierdza ponadto możliwość powoływania do Rady Ministrów kierowników innych republikańskich organów administracji państwowej. Ustawa z dnia 23 lipca 2008 r. o Radzie Ministrów dodaje, iż członkami rządu również są: szef Administracji Prezydenta, przewodniczący Komitetu Kontroli Państwowej, przewodniczący Zarządu Banku Narodowego, przewodniczący komitetów państwowych, kierownik Aparatu Rady Ministrów, przewodniczący Prezydium Narodowej Akademii Nauk, przewodniczący Zarządu Białoruskiego Republikańskiego Związku Organizacji Konsumenckich i ,inne osoby urzędowe na podstawie postanowienia Prezydenta Republiki Białoruś" (art. 4). Trudno nie oprzeć się wrażeniu, iż włączenie do składu rządu pia-

36 W. Rowdo, Srawnitielnaja..., op. cit., s. 139.

37 W. Cziernow, Struktura wysszej ispołnitielnoj i zakonodatielnoj własti, (w:) R. Vainiene, E. Królikowska, J. Płoskonka i W. Romanow (red.), Biełaruś. Scienarii rieform, Warszawa 2003, s. 39.

38 J. Zieliński, Rząd Republiki Białoruś, (w:) E. Zieliński, J. Zieliński, Rządy w państwach Europy, t. 3, Warszawa 2006, s. 38. 
stunów wymienionych funkcji i stanowisk zostało pomyślane jako stworzenie dogodnych organizacyjnych przesłanek objęcia ich kontrolą prezydencką.

Analizując relacje między prezydentem a rządem w pierwszej kolejności należy wspomnieć o suwerennej roli prezydenta w kreacji jego składu, będącej jedną z podstawowych cech białoruskiego modelu systemu rządów i prezydentury. Prezydent określa nie tylko strukturę, liczbę jego członków, w tym zastępców premiera, ale również całkowicie samodzielnie ich wszystkich powołuje. Co prawda, prezydent mianuje premiera formalnie za zgodą Izby Reprezentantów, to jednak przysługuje mu skutecznie „dyscyplinujący” środek wobec izby pierwszej parlamentu białoruskiego, jakim jest uprawnienie do rozwiązania tej izby i zarządzenia nowych wyborów w razie dwukrotnego odrzucenia przez nią wniosku o mianowanie premiera. Zgodnie z ustawą z dnia 23 lipca 2008 r. o Radzie Ministrów zastępcy premiera, ministrowie, a także wchodzący w skład rządu przewodniczący komitetów państwowych są powoływani przez prezydenta bez obowiązku zasięgania opinii w tej sprawie premiera czy Izby Reprezentantów. Oznacza to, że premier formalnie jest pozbawiony wpływu na skład Rady Ministrów, organu, którym przecież kieruje. Dodajmy, że zgody prezydenta wymaga powołanie i odwołanie przez Radę Ministrów zastępcy ministra; trzech jednak zastępców powołuje sam prezydent (Ministra Spraw Wewnętrznych, Ministra Obrony i Ministra ds. Nadzwyczajnych). Aby mieć pełne wyobrażenie o prezydenckiej władzy w odniesieniu do obsady stanowisk w szeroko pojmowanej administracji rządowej, wskażmy jeszcze, że prezydent powołuje i odwołuje przewodniczących komitetów państwowych niewchodzących w skład rządu oraz kierowników innych organów administracji państwowej szczebla republikańskiego. Obowiązuje przy tym zasada, że organy tego typu są podległe Radzie Ministrów, ale w sferach działalności przewidzianych aktami ustawodawczymi mogą być podporządkowane wyłącznie prezydentowi ${ }^{39}$.

Prezydent został wyposażony także we władzę absolutną w rozstrzyganiu o losie rządu w określanym składzie i dokonywaniu w tym składzie zmian. Przysługuje mu bowiem prawo podjęcia z własnej inicjatywy, bez uzyskania zgody Izby Reprezentantów, decyzji o odwołaniu lub dymisji rządu lub zdymisjonowaniu któregokolwiek jego członka. Rozwiązanie to prowadzi do wysunięcia na pierwszy plan, niestwierdzonej wprost $\mathrm{w}$ konstytucji, odpowiedzialności rządu przed prezydentem, kosztem deklarowanej w ustawie zasadniczej formuły odpowiedzialności rządu przed parlamentem (art. 106). Twierdzenie to jest jeszcze bardziej zasadne w kontekście uzależnienia od woli prezydenta skuteczności parlamentarnego wotum nieufności wobec rządu oraz odmowy wyrażenia mu wotum zaufania. Wyrażona w ten sposób przez Izbę Reprezentantów dezaprobata dla rządu może bowiem skutkować podjęciem przez prezydenta decyzji o jej rozwiązaniu. 
Równie mocnego podkreślania wymaga fakt konstytucyjnego zapewnienia prezydentowi możliwości kierowania Radą Ministrów poprzez przyznanie mu prawa do przewodniczenia posiedzeniom tego organu. Zwraca też uwagę usytuowanie przez ustawę o Radzie Ministrów w składzie jego organu wewnętrznego, Prezydium Rady Ministrów, osoby ze ,sfer” prezydenckich, mianowicie szefa Administracji Prezydenta. W relacjach między białoruską głową państwa a rządem duże znaczenie mają też obowiązki wobec prezydenta: premiera - informowania o podstawowych kierunkach działalności rządu i o jego wszystkich ważniejszych decyzjach; całej Rady Ministrów - przedłożenia projektu budżetu państwa i sprawozdania z jego wykonania.

Ważnym przejawem zwierzchnictwa prezydenta nad rządem jest oprócz tego przysługujące mu nieograniczone prawo do uchylania aktów tego organu; prawo to obejmuje również akty rządowe niekolidujące z innymi aktami prawnymi, a wystarczającym kryterium uchylenia jest uznanie aktu za niecelowy ${ }^{40}$.

Innego rodzaju świadectwem powiązania rządu z prezydentem jest zbieżność okresu działania Rady Ministrów z kadencją białoruskiej głowy państwa. Konstytucja nakłada mianowicie na rząd obowiązek złożenia dymisji przed nowo wybranym Prezydentem Republiki Białoruś.

Konstytucja daje prezydentowi uprawnienia do ingerencji w działalność organów władzy publicznej nie tylko szczebla republikańskiego, ale też i lokalnego. Przekazała bowiem jemu uprawnienie do kontroli przestrzegania ustaw przez lokalne organy administracji i samorządu. Prezydent nie posiada jednak prawa do dokonywania zmian w aktach wspomnianych organów; może on jedynie zawiesić obowiązywanie zakwestionowanego aktu.

Oddziaływanie na władzę sądowniczą umożliwiają Prezydentowi Republiki Białoruś posiadane przez niego rozległe uprawnienia do decydowania o obsadzie osobowej organów tę władzę tworzących. Mianuje on - za zgodą Rady Republiki - przewodniczących najwyższych instancji sądowych, tj. Sądu Najwyższego i Naczelnego Sądu Gospodarczego Republiki Białoruś; taką decyzję podejmuje ponadto w sprawie powierzenia funkcji przewodniczącego - również zaliczanego przez konstytucję do organów władzy sądowniczej - Sądu Konstytucyjnego. Prezydent mianuje nie tylko przewodniczących wskazanych organów sądowych, ale i ich sędziów. W przypadku Sądu Najwyższego i Naczelnego Sądu Gospodarczego zasada ta obejmuje wszystkich sędziów, natomiast Sądu Konstytucyjnego - sześciu sędziów, czyli połowę jego składu (sześciu pozostałych mianuje Rada Republiki). Głowa państwa powołuje oprócz tego wszystkich sędziów sądów powszechnych. Wskazane uprawnienia o charakterze personalnym w odniesieniu do władzy sądowniczej w praktyce służą politycznemu uzależnieniu powoływanych osób, nierzadko czyniąc z konstytucyjnej zasady niezawisłości sędziowskiej ustrojową fikcję. 
Elementami aparatu państwowego niezależnymi od prezydenta również nie są prokuratura i Komitet Kontroli Państwowej, traktowane w doktrynie białoruskiej jako organy samodzielne, umiejscowione poza systemem podziału władzy ${ }^{41}$. Zgodnie z konstytucją Prokurator Generalny jest powoływany przez prezydenta i jemu też jest podległy. Prezydent powołuje też przewodniczącego Komitetu Kontroli Państwowej oraz posiada wobec tego Komitetu szerokie uprawnienia nadzorcze.

Wątpliwości nasuwać musi - z punktu widzenia przestrzegania standardów wyborów demokratycznych - przyznanie prezydentowi prawa do mianowania sześciu członków Komisji Republiki Białoruś ds. Wyborów i Przeprowadzenia Referendów Republikańskich, tym bardziej że pozostałych sześciu członków powołuje personalnie powiązana z prezydentem Rada Republiki. Prezydent ponadto powołuje przewodniczącego Banku Narodowego oraz członków jego Zarządu.

Obraz niezwykle silnej prezydentury białoruskiej byłby niepełny bez wskazania kompetencji oraz innych elementów statusu prawnego prezydenta wykraczających poza charakterystykę relacji między nim a władzami: ustawodawczą, wykonawczą i sądowniczą.

Formą aktywności politycznej społeczeństwa, którą prezydent może inicjować, są przewidziane w konstytucji tego państwa referenda ogólnokrajowe (republikańskie) i referenda lokalne, które mogą być przeprowadzane w celu rozstrzygania o „najważniejszych zagadnieniach życia państwowego i społecznego” (art. 117). Referendum ogólnokrajowe jest zarządzane przez prezydenta z własnej inicjatywy, na wniosek Izby Reprezentantów i Rady Republiki (uchwalany na osobnych posiedzeniach każdej z izb większością bezwzględną głosów pełnych ich składów) lub na wniosek 450 tys. obywateli posiadających prawa wyborcze (w tej liczbie nie mniej niż 30 tys. obywateli w każdym obwodzie i mieście Mińsk). W myśl art. 117 kodeksu wyborczego z dnia 11 lutego 2000 r. prezydent ma prawo odrzucić przedłożony wniosek, jeżeli nie odpowiada on wymogom tego kodeksu i innych aktów ustawodawczych Republiki Białoruś.

W sferze stosunków prezydenta $\mathrm{z}$ obywatelami zawiera się zwracanie się przez niego $z$ orędziami do narodu o stanie państwa i podstawowych kierunkach polityki wewnętrznej i zagranicznej. Jak się wskazuje, ustalanie częstotliwości występowania z takimi orędziami jest uprawnieniem samego prezydenta ${ }^{42}$.

W kontekście zapewnień przedstawicieli reżimu białoruskiego o przestrzeganiu wolności i praw człowieka obywatela, wymowne jest przysługujące prezydentowi uprawnienie, w sytuacjach przewidzianych w ustawach, do zawieszenia lub zakazu przeprowadzenia strajku. W dziedzinie stosunków z obywatelami - w myśl konstytucji - prezydent dysponuje jeszcze uprawnieniem do przyznawania nagród pań- 
stwowych i odznaczeń państwowych, a także ustanawiania świąt państwowych i dni wolnych od pracy.

Konstytucja zawiera szereg postanowień określających rolę białoruskiej głowy państwa w dziedzinie bezpieczeństwa narodowego i bezpieczeństwa państwa. Prezydent kieruje wojskiem, pełniąc funkcję Głównodowodzącego Sił Zbrojnych; powołuje i zwalnia wyższych ich dowódców. Stoi na czele - formowanej przez siebie - Rady Bezpieczeństwa. Do kompetencji prezydenta należy wprowadzanie stanu wojennego, jak i ogłaszanie pełnej lub częściowej mobilizacji. Decyduje również o wprowadzeniu stanu wyjątkowego, na całym terytorium państwa lub jego części, w razie klęski żywiołowej, katastrofy, zaburzeń, którym towarzyszy przemoc lub groźba jej użycia ze strony grupy osób i organizacji, w rezultacie czego powstaje zagrożenie dla życia i zdrowia ludzi. Decyzja prezydenta w tej sprawie podlega zatwierdzeniu Rady Republiki.

Prezydent białoruski został wyposażony w szereg kompetencji wiążących z jego funkcją głowy państwa, jak dotyczących obywatelstwa, prawo łaski, mianowanie i odwoływanie przedstawicieli dyplomatycznych, przyjmowanie listów uwierzytelniających i odwołujących przedstawicieli dyplomatycznych innych państw. Postanowienia białoruskiej konstytucji pozwalają stwierdzić, iż prezydent bez wymogu uzyskiwania jakiegokolwiek upełnomocnienia reprezentuje Republikę Białoruś w stosunkach z innymi państwami i organizacjami międzynarodowymi ${ }^{43}$. Łączy się z tym jego prerogatywa przeprowadzania negocjacji i podpisywania umów międzynarodowych.

Z ideą podziału władzy nie koreluje pozycja prawnoustrojowa struktury organizacyjnej władzy państwowej, mającej podstawę prawną działania w konstytucji (art. 84 ust. 5), jaką jest Administracja Prezydenta Republiki Białoruś, wobec znaczenia której kompetencje zarówno parlamentu, jak i Rady Ministrów schodzą na drugi plan $^{44}$. Zgodnie $\mathrm{z}$ ustanowionym przez prezydenta regulaminem tej Administracji z 23 stycznia 1997 r., jest ona organem zapewniającym działalność prezydenta w dziedzinie polityki kadrowej, ideologii państwa białoruskiego, prawa, przygotowywania, urzeczywistniania i kontroli realizacji decyzji Prezydenta Republiki Białoruś. Praktyczna jej rola w białoruskim systemie politycznym jest niebagatelna: „Administracja prezydenta jest najważniejszym rezerwuarem kadr dla wyższych jednostek zarządzania państwowego w centrum i regionach. Jej liczne działy dublują pracę ministerstw i resortów rządu, wytyczając im określony wektor rozwoju, tak jak w swoim czasie działały wydziały Komitetu Centralnego Komunistycznej Partii Białorusi w stosunku do radzieckiego rządu. Oprócz tego, w Administracji są ześrodkowane siły, które zapewniają , «kierowniczą i przewodnią» rolę prezydenta

43 Ibidem, s. 234.

44 O utworzeniu Administracji Prezydenta i pierwszych latach jej działalności zob. O. Belova, Difficulties of elite formation in Belarus after 1991, (w:) E.A. Korosteleva, C.W. Lawson, R.J. Marsh (red.), Contemporary Belarus. Between Democracy and Dictatorship, London-New York 2003, s. 59 i n. 
w jego wzajemnych stosunkach z organami władzy ustawodawczej i ustawodawczej"45. W uzupełnieniu dodajmy, iż szefa Administracji i wszystkie osoby sprawujące w niej wyższe stanowiska powołuje prezydent.

Sklasyfikowanie skonstruowanego przez konstytucję Republiki Białoruś systemu rządów nastręcza sporo trudności. Najczęściej bywa on umieszczany w grupie systemów mieszanych: semiprezydenckich ${ }^{46} \mathrm{i}-$ jako podtyp tych systemów lub jako odrębny system - prezydencko-parlamentarnych ${ }^{47}$. Nierzadkie jest również nazywanie tego systemu półprezydenckim ${ }^{48}$. Bywa, iż nadaje się mu miano prezydenckiego ${ }^{49}$, czy superprezydenckiego ${ }^{50}$.

Z uwzględnieniem rzeczywistej postaci prezydentury białoruskiej, ukształtowanej w praktyce politycznej, wynikający niej reżim polityczny bywa natomiast traktowany jako jedna $\mathrm{z}$ odmian systemu autorytarnego ${ }^{51}$, demokratura ${ }^{52}$, forma specyficznego dla państw członków Wspólnoty Niepodległych Państw - modelu „państwa aparatczyków”53 lub reżimu tzw. sułtańskiego ${ }^{54}$. Nie ma żadnej przesady w określaniu rzeczywistych relacji pomiędzy prezydentem a pozostałymi organami państwa, jak i społeczeństwem, dyktaturą prezydencką ${ }^{55}$ ewentualnie dyktaturą wybieralną (wyborczą) $)^{56}$. Tym, co odróżnia białoruski system monistycznego sprawowania władzy politycznej od klasycznych systemów totalitarnych, to jest ulokowanie centrum dyspozycji politycznej nie w monopartii, lecz w osobie prezydenta.

45 W. Rowdo, Srawnitielnaja..., op. cit., s. 140.

46 R. Elgie, Semi-Presidentialism. Sub-Types and Democratic Performance, Oxford 2011, s. 24; M. Kubat, Presidentialism and Parliamentarism: A Case of Post-Communist Europe and Pos-Soviet States, "Acta Universitatis Carolinae" 2001, Studia Territoriala, s. 21; Yu-Shan Wu, Clustering of Semi- Presidentialism: A First Cut, (w:) R. Elgie, S. Moestrup, Yu-Shan Wu (red.), Semi-Presidentialism and Democracy, Palgrave Macmillan 2011, s. 23. Tak np. R. Elgie, Semi-Presidentialism..., op. cit., s. 29; L. Gönenç, Prospects for Constitutionalism in Post-Communist Countries, The Hague-London-New York 2002, s. 291 i n.; O. Protsyk, Semi-Presidentialism under PostCommunism, (w:) Semi-Presidentialism and Democracy, s. 101 i 108; T. Sedelius, Post-Communism..., op. cit., s. 91.

48 Tak np. J. Ciapała, P. Mijal, op. cit., s.39; M. Czerwiński, Białoruś, (w:) M. Barański (red.), Systemy polityczne państw Europy Środkowej i Wschodniej, Katowice 2005, s. 46; idem, Prezydent..., op. cit., s. 203; J. Zieliński, Rząd..., op. cit., s. 31 i 37.

49 J.M. Carey, Presidential versus Parliamentary Government, (w:) C. Ménard. M.M. Shirley (red.), Handbook of New Instutional Economics, Berlin-Heidelberg 2008, s. 93. Zob. też S. Hansen, Belarus, (w:) G. Robbers (red.), Encyclopedia of World Constitutions, New York 2007, s. 85.

50 Tak np. T. Bodio, J. Wojnicki, P. Załęski, Transformacja ustrojowa państw postsocjalistycznych, (w:) K.A. Wojtaszczyk, W. Jakubowski (red.), Społeczeństwo i polityka, Warszawa 2007, s. 478-479; W. Rowdo, Srawnitielnaja..., op. cit., s. 136.

51 Zob. np. A. Antoszewski, R. Herbut, Systemy polityczne współczesnego świata, Gdańsk 2001, s. 39; T. Carothers, The End of the Transitional Paradigm, „Journal of Democracy” 2002, Vol. 13, No 1, s. 5 i n.

52 Zob. B. Górowska, Okoliczności i rezultaty zmiany Konstytucji Białorusi, „Polityka Wschodnia” 1997, nr 1, s. 99 i n.

53 Zob. M. Czerwiński, Prezydent..., op. cit., s. 200.

54 Zob. np. S. Eke, T. Kuzio, Sultanism in Eastern Europe: The Socio-Political Roots of Authoritarian Populism in Belarus, "Europe-Asia Studies" 2000, Vol. 3, s. 523 i n.

55 Tak np. T. Sedelius, Post-Communism..., op. cit., s. 101; J. Sobczak, Republika Białorusi, (w:) E. Gdulewicz (red.), Ustroje państw współczesnych, t. 2, Lublin 2002, s. 16 i 21; J. Wojnicki, Ewolucja system politycznego Białorusi, (w:) J. Zaleśny (red.), Zagadnienia ustrojowe państw poradzieckich, Warszawa 2010, s. 70.

56 E.A. Korosteleva, C.W. Lawson, E.J. Marsh, Introduction: Paradoxes of Democratisation in Post- communist Belarus, (w:) Contemporary Belarus..., op. cit., s. 15. 


\section{BIBLIOGRAFIA}

Antoszewski A., R. Herbut, Systemy polityczne współczesnego świata, Gdańsk 2001.

Belova O., Difficulties of elite formation in Belarus after 1991, (w:) E.A. Korosteleva, C.W. Lawson, R.J. Marsh (red.), Contemporary Belarus. Between Democracy and Dictatorship, London-New York 2003.

Bodio T., J. Wojnicki, P. Załęski, Transformacja ustrojowa państw postsocjalistycznych,(w:) K.A. Wojtaszczyk i W. Jakubowski (red.), Społeczeństwo i polityka, Warszawa 2007.

Carey J.M., Presidential versus Parliamentary Government, (w:) C. Ménard. M.M. Shirley (red.), Handbook of New Instutional Economics, Berlin-Heidelberg 2008.

Carothers T., The End of the Transitional Paradigm, „Journal of Democracy” 2002, Vol. 13, No 1.

Ciapała J., P. Mijal, Prawo wyborcze na urząd prezydenta na Białorusi, (w:) S. Grabowska i R. Grabowski (red.), Prawo wyborcze na urząd prezydenta w państwach europejskich, red. Warszawa 2007.

Czerwiński M., Białoruś, (w:) M. Barański (red.), Systemy polityczne państw Europy Środkowej i Wschodniej, Katowice 2005.

Czerwiński M., Prezydent jako głowa władzy wykonawczej - model białoruski, (w:) M. Drzonek i A. Wołek (red.), Władza wykonawcza w Polsce i Europie, Kraków-Nowy Sącz 2009.

Czerwiński M., Zgromadzenie Narodowe Białorusi, Warszawa 2008.

Cziernow W., Struktura wysszej ispołnitielnoj i zakonodatielnoj własti, (w:) R. Vainiene, E. Królikowska, J. Płoskonka i W. Romanow (red.), Biełaruś. Scienarii rieform, Warszawa 2003.

Czudakow M., Bałans włastiej i drugije principy organizacji i diejatielnosti gosudarstwa: princip sdierżek i protiwowiesow w konstitucii Riespubliki Biełaruś, „Probliemy Uprawlienija” 2008, nr 1.

Eke S., T. Kuzio, Sultanism in Eastern Europe: The Socio-Political Roots of Authoritarian Populism in Belarus, "Europe-Asia Studies" 2000, Vol. 3.

Elgie R., Semi-Presidentialism. Sub-Types and Democratic Performance, Oxford 2011.

Górowska B., Okoliczności i rezultaty zmiany Konstytucji Białorusi, „Polityka Wschodnia” 1997, nr 1.

Gönenç L., Prospects for Constitutionalism in Post-Communist Countries, The Hague-London-New York 2002.

Hansen S., Belarus, (w:) G.Robbers (red.), Encyclopedia of World Constitutions, New York 2007.

Kodawbowicz W.A., W.A. Krugłow, Konstitucjonnoje prawo Riespubliki Biełaruś, Mińsk 2012.

Korosteleva E.A., C.W. Lawson, E.J. Marsh, Introduction: Paradoxes of Democratisation in Post- communist Belarus, (w:) E.A. Korosteleva, C.W. Lawson, R.J. Marsh (red.), Contemporary Belarus. Between Democracy and Dictatorship London-New York, 2003.

Kowalski J., Konstytucja Federacji Rosyjskiej a rosyjska i europejska tradycja konstytucyjna, Warszawa-Poznań 2009.

Kubat M., Presidentialism and Parliamentarism: A Case of Post-Communist Europe and Pos-Soviet States, "Acta Universitatis Carolinae" 2001, Studia Territoriala. 
Kuczinskij W., Problemy zabezpieczenia podziału władz w Republice Białoruś. Historia, stan obecny, perspektywy, (w:) A. Łopatka (red.), Ku konstytucji społeczeństwa obywatelskiego, Warszawa 1995.

Łagun D.A., Juridiczieskij status wriemiennych diekrietow, „Wiesnik BDU” 2010, seria 3, nr 3.

Łatyszonek O., E. Mironowicz, Historia Białorusi od połowy XVIII do końca XX wieku, Białystok 2002, wyd. II Białystok 2010.

Maryskin A.W. Osnowy konstitucjonnogo prawa. Mińsk 2005.

Maszkiewicz M., Republika Białoruś, (w:) W. Baluk i A. Czajowski (red.), Ustroje polityczne krajów Wspólnoty Niepodległych Państw, Wrocław 2007.

Pietrowa M.S., Normatiwnyje prawowyje akty Prezidienta Riespubliki Biełaruś i ich miesto w sistiemie zakonodatielstwa, (w:) Uprawlienije w socjalnych i ekonomiczieskich sistiemach. XVII mieżdunarodnaja nauczno-prakticzieskaja konfieriencija, Minsk, 2-6 ijunia 2008 g., Mińsk 2008.

Protsyk O, Semi-Presidentialism under Post-Communism, (w:) R. Elgie, S. Moestrup, Yu-Shan Wu (red.), Semi-Presidentialism and Democracy. Palgrave Macmillan 2011.

Rowdo W., Srawnitielnaja politołogija, cz. 3, Politiczieskaja sistiema Riespubliki Biełaruś, Wilno 2009.

Rychlik J., Zasady zmiany Konstytucji Republiki Białorusi, (w:) R. Grabowski i S. Grabowska (red.), Zasady zmiany konstytucji w państwach europejskich, Warszawa 2008.

Sedelius T. The Tug-of-War between Presidents and Prime Ministers Semi-Presidentialism in Central and Eastern Europe, Örebro 2006.

Sobczak J., Republika Białorusi, (w:) E. Gdulewicz (red.), Ustroje państw współczesnych, t. 2, Lublin 2002 .

Stalin J., Zagadnienia leninizmu, Warszawa 1949.

Szymczak T., Ewolucja instytucji prezydenta w socjalistycznym prawie państwowym, Łódź 1976.

Szymczak T., Republika Białoruś, (w:) W. Brodziński, D. Górecki, K. Skotnicki, T. Szymczak, Wzajemne stosunki między władzą ustawodawczą a wykonawczą (Białoruś, Czech, Litwa, Rumunia, Słowacja, Węgry), Łódź 1996.

Tarasowa J.A., Potieriannaja altiernatiwa: stanowlienije nowoj politiczieskoj sistiemy Rossii w 19901993 gg., Sankt Petersburg 2012.

Usov P., Powstanie, konsolidacja i funkcjonowanie reżimu neoautorytarnego na Białorusi w latach 1994-2010, Warszawa 2014.

Wasiliewicz G.A., Konstitucjonnoje prawo Riespubliki Biełaruś, Mińsk 2009.

Wilson A., Belarus. The Last European Dictatorship, New Haven-London 2011.

Wojnicki J., Ewolucja system politycznego Białorusi, (w:) J. Zaleśny (red.), Zagadnienia ustrojowe państw poradzieckich, Warszawa 2010.

Yu-Shan Wu, Clustering of Semi- Presidentialism: A First Cut, (w:) R. Elgie, S. Moestrup, Yu-Shan Wu (red.), Semi-Presidentialism and Democracy, Palgrave Macmillan 2011.

Zaleśny J., System konstytucyjny Białorusi, Warszawa 2011.

Zieliński J., Rząd Republiki Białoruś, (w:) E. Zieliński, J. Zieliński (red.), Rządy w państwach Europy, t. 3, Warszawa 2006. 
CONSTITUTIONAL MODEL OF PRESIDENCY IN THE REPULIC OF BELARUS

This work is focused on the constitutional determinants of the model of presidency in the Republic of Belarus, implemented by Alexander Lukashenko for more than 20 years now. The basic feature of this model is the head of state having extremely strong and vast power, greatly extending the sphere of executive power. The Belarusian president is able to exert his power over the whole system of public authority bodies, and does so. He can be called the "effective force" of the functioning of the state, making his office its actual headquarters. There is also no exaggeration in referring to the relations occurring in political practice between him and all other entities of the state apparatus as a presidential dictatorship, and to the whole political regime as the "hard" form of an authoritarian system. The provisions of the constitution of the Republic of Belarus of 15 March 1994 with the amendments made as a result of the referendum of 24 November 1996, making the president superior to the other state authorities, and thus making the principle of separation of powers included in Article 6 an empty declaration, provide the legal premises for the head of state acting in this way. The constitutional domination of the president in the structure of the state authority is strengthened even more by the political activity of Alexander Lukashenko, making his authority near absolute.

Keywords Republic of Belarus, system of government, constitutional model of presidency, President of The Republic of Belarus

Słowa kluczowe: Republika Białoruś, system rządów, konstytucyjny model prezydentury, Prezydent Republiki Białoruś 